\title{
GRANULOMETRY AND ENERGY CONSUMPTION AS INDICATORS OF DISINTEGRATION EFFICIENCY IN A HAMMER MILL ADAPTED TO EXTRACTING ARROWROOT STARCH (Maranta arundinacea) IN COMPARISON TO STARCH EXTRACTION FROM CASSAVA
}

\author{
Fabiano P. Branco ${ }^{1 *}$, Marco H. Naka ${ }^{2}$, Marney P. Cereda ${ }^{3}$ \\ ${ }^{1 *}$ Corresponding author. Universidade Católica Dom Bosco/ Campo Grande - MS, Brasil. \\ E-mail: fabiano@ucdb.br | ORCID ID: https://orcid.org/0000-0003-0398-2102
}

\author{
KEYWORDS \\ Appropriate \\ Technology, Small \\ producers, \\ Mechanization, \\ Agribusiness.
}

\begin{abstract}
The commercial sector of starch extraction has fully automated plants with a minimum scale of 200 ton.day $^{-1}$, which extracts starch from maize and cassava in Brazil. Although these starches are commodities, the market demands starches with special properties obtained without chemical modifications. A higher-priced starch can compensate for small-scale extraction, as in the case of arrowroot starch, which would correspond to an alternative income for the producer. As a small-scale equipment was not available in Brazil, it was necessary to adapt a hammer mill for arrowroot starch extraction, which should have a performance similar to that obtained from cassava roots using industrial grinders. The degree of disintegration and energy consumption were adopted as the efficiency indexes. The hammer mill was equipped with two perforated plates. The results showed that use of an adapted hammer mill provides an average diameter of $74.64 \pm 0.09 \mu \mathrm{m}$ for perforated plate 1 (TP1) and $76.62 \pm 0.06 \mu \mathrm{m}$ for TP2; these results were equivalent to those obtained with cassava in the respective perforations which, in turn, was comparable to the degree of grinding obtained with large industrial equipment. The specific energy consumption needs for arrowroot disintegration varied from 31.47 to $48.91 \mathrm{~kJ}^{\mathrm{kg}}{ }^{-1}$, which was considered close to that calculated for large-scale industrial cassava roots grinders, reported at $37.03 \mathrm{~kJ}_{\mathrm{kg}}{ }^{-1}$.
\end{abstract}

\section{INTRODUCTION}

Arrowroot (Maranta arundinacea) stands out among the potential raw materials for starch extraction; arrowroot has a Latin American origin and is native to some places between Panama and Ecuador (Granados et al., 2014). Its rhizomes have a moisture content of 68 to $75 \%$, with starch ranging from 25 to $30 \%$ (w.b.), depending on the variety and crop conditions (Leonel \& Cereda, 2002; Malinis \& Pacardo, 2012). Its starch is appealing to the European market owing to its reported special properties for fine confectionery (Sá et al., 2015); specifically, in England, the mixture of wheat flour with arrowroot starch is considered the best to make puddings and bakery creams (Guilherme et al., 2019).

Owing to the lack of large-scale production, authentic arrowroot starch is hardly found in the market and is expensive, often encouraging frauds. According to Moreno et al. (2017), a kilogram of arrowroot starch in the Brazilian market ranged from US\$ 3.89 to US\$ 5.18, whereas in the international market $450 \mathrm{~g}$ may reach US\$ 22.19.

Comparison of arrowroot with cassava roots (Manihot esculenta) is unavoidable because of the similarities between them. Also from South America, cassava is used in several Brazilian starch extraction industries, and both raw materials have 64 to $66 \%$ moisture and about $31 \%$ (w.b.) of starch (Da et al., 2013). However, cassava roots have reached an average price of US\$ 0.95.ton ${ }^{-1}$ in 2017, in Mato Grosso do Sul, a Brazilian state placed on the center-west region, that has starch industries with a total capacity of 185 thousand tons of starch per year (Groxko, 2016). These industries could have complement or replace cassava with arrowroot as the raw material.

Despite the advantage of a higher starch price, producers of arrowroot have to overcome certain limiting factors to go to the market with starch production. The extraction efficiency is low because arrowroot is cultivated and processed at a very small scale, and uses Brazilian

\footnotetext{
${ }^{2}$ Instituto Federal de Mato Grosso do Sul/ Campo Grande - MS, Brasil.

${ }^{3}$ Centro de Tecnologia e Análise do Agronegócio (CeTeAGro), Universidade Católica Dom Bosco/ Campo Grande - MS, Brasil.

Received in: 5-15-2018
}

Accepted in: 3-8-2019 
cassava flour machinery for the extraction (Moreno et al., 2017). Furthermore, handmade starch extraction requires more physical work, which is often associated with unhealthy and non-ergonomic activities (Barth et al., 2016).

The needed unit operations for arrowroot starch extraction are the same as those for other roots, tubers, and rhizomes. These include disintegration, extraction and purification, concentration, and finally, drying. Disintegration by grating/milling is the most important (Sajeev et al., 2012), as it open the plant cell walls and exposes the starch granules within (Saengchan et al., 2015).

In both large-scale and small-scale industries, graters are used widely. They consist of rotating cylindrical containers with several saw blades fixed side by side, longitudinally separated by $10 \mathrm{~mm}$ (Sajeev et al., 2012). This type of grater promotes size reduction through friction and shearing, and must be replaced or sharpened periodically to ensure that the high disintegration efficiency remains high (Sajeev et al., 2012). In the same concept, but for small scale use, Sheriff \& Balagopalan (1999) developed a multipurpose raw material grater for starch extraction, with a capacity of 75-125 kg.h-1 . They evaluated the performance for various tuber and root crops. Sajeev \& Balagopalan (2005) studied grating for starch extraction from yam, cassava, and potato. The capacity of the machine varied from $120-200 \mathrm{~kg} \cdot \mathrm{h}^{-1}$ of raw material, depending on the crop.

Although hammer mills have been widely used in China, they are less used in starch industries in Latin America (Cereda \& Vilpoux, 2003). The hammers are mounted on a rotating shaft. On the underside of the machine, plates perforated with round or oval holes are fixed as sieves that allow the flow of the disintegrated mass
(Souza et al., 2010). The sieves improve the efficiency by preventing the flow of lager particles that are not well disintegrated.

Due to the need for an equipment that meets the minimum conditions and still operates at the small scale, it was necessary to develop and evaluate a machine that is at least as effective as the industrial level for processing cassava starch, is safe and inexpensive, and enables farmers to improve living conditions through increased production and income. These requirements led to the selection of an adapted hammer that was evaluated in this paper to meet the first operation in the initial processing of arrowroot starch extraction.

\section{MATERIAL AND METHODS}

\section{Hammer mill characterization and its adaptations for starch extraction}

A hammer mill (Pegorari Agricultura Têxtil, Itapira - SP, Brazil) was used for disintegrating the raw material (Figure 1A) after being adapted with a rotor-cutter mounted in a grinding box with two sets of 6 hammers, $140 \mathrm{~mm}$ in width and $270 \mathrm{~mm}$ in diameter. The adaptation involved the manufacture of a new rotor, which is more suitable for raw materials with about $60 \%$ humidity. The rotor-cutter was removed and replaced with a new configuration consisting of 45 rectangular hammers, $38.1 \mathrm{~mm}$ in width, $4.76 \mathrm{~mm}$ in thickness, and $80 \mathrm{~mm}$ in length, which were arranged in 3 sets of 7 hammers with 3 other sets of 8 hammers interleaved. The rotor width was maintained in the new adopted diameter of $280 \mathrm{~mm}$, so that they could be inserted into the original grinding box, as shown in Figure 1B.

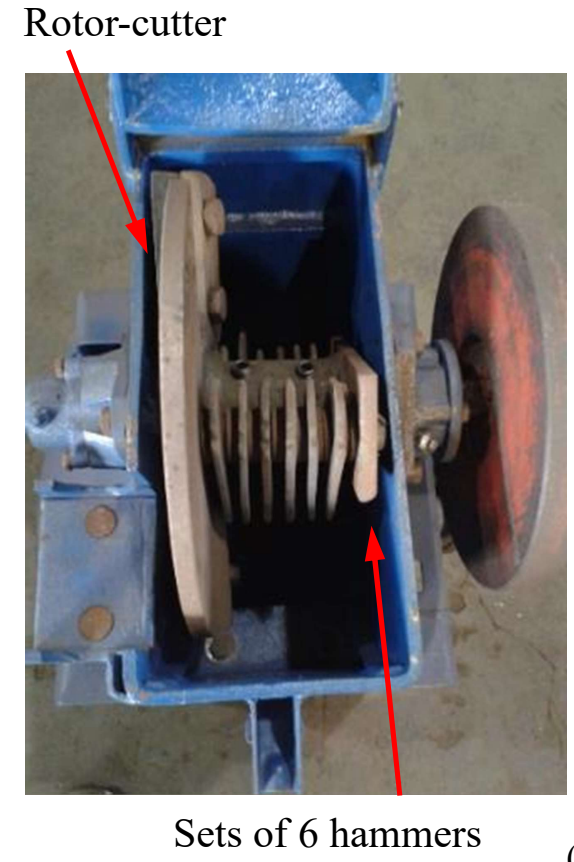

(A)

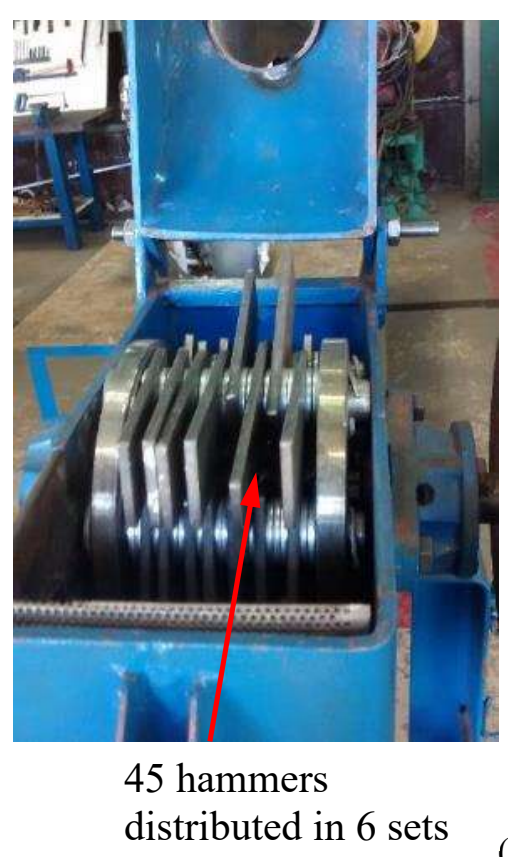

(B)

FIGURE 1. (A) Original commercial hammer mill of the Pegorari Agriculture Têxtil, developed to mill cereals (two sets of 6 hammers and rotor-cutter) and (B) adaptation to raw materials with about $60 \%$ humidity (rotor with 45 hammers distributed in 6 sets). 
The adapted equipment is shown in Figure 2, where the feeding tube for raw material has about $50 \mathrm{~mm}$ diameter ( 2 inch as diameter) and is $300 \mathrm{~mm}$ in length, which was welded to the top of the mill to prevent operator access to the rotor while the equipment is in operation. The equipment is driven by a single-phase electric engine $(220 \mathrm{~V}, 2 \mathrm{HP})$ with $1.5 \mathrm{~kW}$ and a nominal rotation of $1700 \mathrm{rpm}$. The mechanical power is transmitted through of a pair of belts with a 1:1 ratio on the pulleys, which produces the same rotation on the mill shaft.

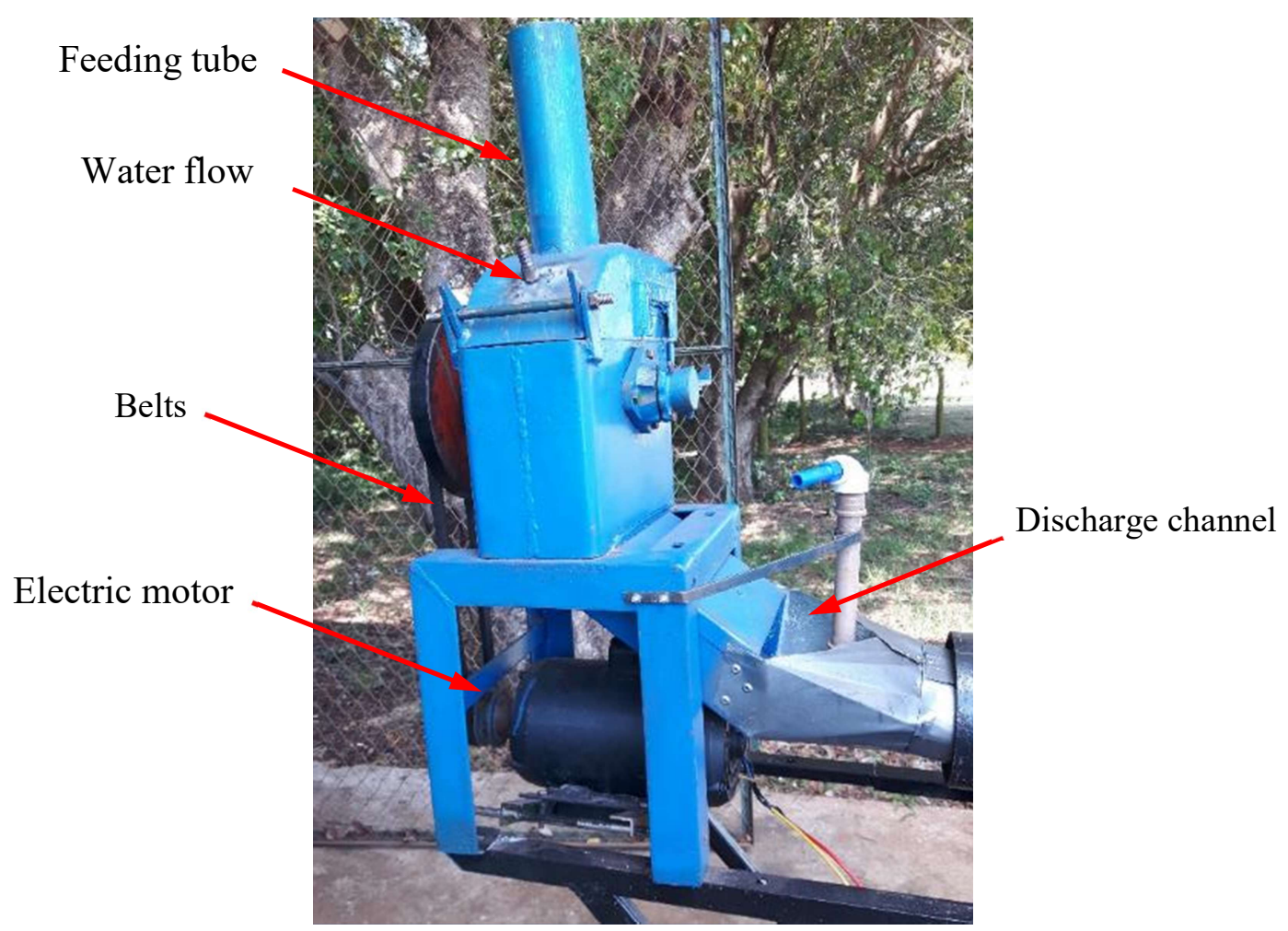

FIGURE 2. Hammer mill adapted for raw materials with about $60 \%$ of humidity.

Between the rotor and the discharge channel, a perforated steel plate is positioned to retain the disintegrated material until the particle size reaches a diameter smaller than the diameter of the holes. The three perforated plates (TP1, TP2, and TP3) used had the same size and a total area of $0.056 \mathrm{~m}^{2}$, as described in Table 1 in relation to the diameter of the holes (D), distance between the holes (Xc) and percentage of open area (Aa).

TABLE 1. Perforated plates characteristics and evaluated variables: hole diameter (D $\mathrm{mm})$, distance between holes (Xc mm), and percentage of open area $(\mathrm{Aa} \%)$.

\begin{tabular}{cccc}
\hline Type & $\mathrm{D}(\mathrm{mm})$ & $\mathrm{Xc}(\mathrm{mm})$ & Aa $(\%)$ \\
\hline TP1 & 1.2 & 2.2 & 27.3 \\
TP2 & 1.5 & 3.0 & 22.5 \\
TP3 & 1.8 & 3.0 & 32.4 \\
\hline
\end{tabular}

These perforated plates were the same ones used in industrial equipment for extracting cassava starch (Cereda \& Vilpoux, 2003). To evaluate the variables, samples of cassava roots and arrowroot rhizomes were used with 3 repetitions for each type. The choice of cassava is due to the existence of more related information in literature, leading to a more reasoned discussion regarding the results obtained in the tests.

In order to approximate what occurs in starch extraction industries, it was necessary to provide water using a hydraulic system in the structure of the original hammer mill. The purpose of the operation with water is to dilute the disintegrated mass and aid in the drag during disintegration, thus promoting cleaning of the hammers. The water flow rate was kept fixed at $0.75 \mathrm{~L} . \mathrm{min}^{-1}$ during the disintegration operation.

\section{Raw materials for starch extraction}

The raw materials used were cassava roots named fécula branca and arrowroot rhizomes named common, both grown in Campo Grande (MS) and harvested manually in October 2015.

\section{Mass flow rate of the raw material and electric energy consumption of the hammer mill}

The raw material mass flow rate in the hammer mill was calculated by counting the time required to disintegrate the mass of $10 \mathrm{~kg}$ of raw material and the energy consumption was expressed per kilogram of raw material disintegrated; specific energy consumption (Ee) was defined according to [eq. (1)] (Souza et al., 2010).

$$
\mathrm{E}_{\mathrm{e}}=\frac{\mathrm{P}}{\dot{\mathrm{m}}_{\mathrm{m}}}
$$

Where:

$$
\begin{aligned}
& \mathrm{E}_{\mathrm{e}}-\text { specific energy consumption }\left(\mathrm{kJ} \cdot \mathrm{kg}^{-1}\right) \\
& \dot{\mathrm{m}}_{\mathrm{m}}-\text { Mass flow rate of raw material }\left(\mathrm{kg} \cdot \mathrm{s}^{-1}\right) \text {, and } \\
& \mathrm{P}-\text { Electric power consumption }(\mathrm{kW}) .
\end{aligned}
$$


Therefore, specific energy consumption of the adapted hammer mill was compared with the commercially available data of graters operating in similar conditions in terms of particle size and humidity. The reference for specific energy consumption was based on the description found for a commercial grater available in the manufacturers' catalogs: Bosida ${ }^{\circledR}(2016)$, EBS ${ }^{\circledR}(2015)$, Konex ${ }^{\circledR}$ (2016) and Larsson ${ }^{\circledR}(2016)$ for a grater processing cassava, potato, and sweet potato, as no information on arrowroot was found in literature. Each commercial grater was considered in three aspects: raw material, mass flow rate, and drive power. With these values, a curve was plotted, and its slope can be considered as the specific consumption (Ee) per kilogram of disintegrated raw material.

\section{Granulometric distribution and mean particle size}

To evaluate the mean mass diameter, the particle size distribution of disintegrated particles was determined according to the methodology reported by Sajeev et al. (2012), where in each test the disintegrated mass was sieved through four ASTM sieves: $20(850 \mu \mathrm{m}), 40(425 \mu \mathrm{m}), 80$ $(180 \mu \mathrm{m})$, and $170(90 \mu \mathrm{m})$. First, the samples were set with a weight of $100 \mathrm{~g}$ of disintegrated raw material, evaluated in triplicate. Next, the grated portions retained in each plate were removed, weighed and dried in an air circulation oven (Marconi, MA035/1152, Piracicaba - SP, Brazil), that was set at $105^{\circ} \mathrm{C}$ for 72 hours. Finally, the samples were weighed to be expressed as a percentage of the dry mass. This value was used to determine the dry mass retained in each sieve $\left(\mathrm{x}_{\mathrm{i}}\right)$ and was expressed as a percentage. The comparison between treatments for each sieve used the Sauter Diameter $\left(D_{s}\right)$, which relates the particle diameter, whose surface/volume ratio is the same in all particles and was calculated by [eq. (2)] (Jordan et al., 2016):

$$
\mathrm{D}_{\mathrm{s}}=\frac{1}{\sum \frac{\mathrm{x}_{\mathrm{i}}}{\mathrm{D}_{\mathrm{pi}}}}
$$

Where:

$$
\begin{aligned}
& D_{s}-\text { Sauter diameter }(\mu \mathrm{m}) ; \\
& x_{i}-\text { Perceptual dry mass retained in each sieve, and } \\
& D_{p i}-\text { Mean diameter of each sieve }(\mu \mathrm{m}) .
\end{aligned}
$$

Using the same methodology, the grating mass of an industrial grater with a perforated plate of $1.2 \mathrm{~mm}$ was used as a standard for the granulometric distribution, which was supplied by Fecularia Ponta Porã (MS, Brazil), an industry which commercially extracts cassava starch. Two moments was selected to collect the grated mass. The first soon after changing the blades of the saws $(\mathrm{C} 1)$ in which the blades were new. The second after 14 days, when it was its replacement was imminent, that is, when the saws were worn out (C2), allowing evaluation of the average granulometry used in the industry and to evaluate if the use of a hammer mill allows circumvention of these technical interruptions.

\section{Statistical analysis}

The results were statistically analyzed, and the means were compared using Tukey's test with 5\% significance level. For the test, the statistical analysis of the experimental design would be as follows:

\begin{tabular}{lc}
\hline Variables & \\
\hline Raw materials & 2 \\
Equipment's & 2 \\
Plates & 3 \\
Repetitions & 3 \\
Degree of freedom (DF) & 35 \\
Total & 36 \\
\hline
\end{tabular}

\section{RESULTS AND DISCUSSION}

\section{Mass flow rate and energy consumption}

To feed raw material to the hammer mill, the mass flow rate obtained in the tests ranged from $1.84 \mathrm{~kg} \cdot \mathrm{min}^{-1}$ $\left(0.030 \mathrm{~kg} . \mathrm{s}^{-1}\right)$ to $2.86 \mathrm{~kg} \cdot \mathrm{min}^{-1}\left(0.047 \mathrm{~kg} . \mathrm{s}^{-1}\right)$, depending on the size of the rhizomes and roots, which represents a processing capacity of 8 hours per day, varying from 880 to $1400 \mathrm{~kg}$ of rhizomes or roots processed. The specific power data varied from 31.47 to $48.91 \mathrm{~kJ}^{\mathrm{kg}} \mathrm{kg}^{-1}$, that was obtained by Equation 1 considering an electric motor of $1.5 \mathrm{~kW}$.

The fitting linear curves obtained in Figure 3 represent the relationship between the specific energy consumption of the industrial grater for cassava, potato, and sweet potato and the power obtained from the manufacturers' catalogs. The straight line shows that energy consumption increased linearly with the increase in the power of the engines of the harvesters. 


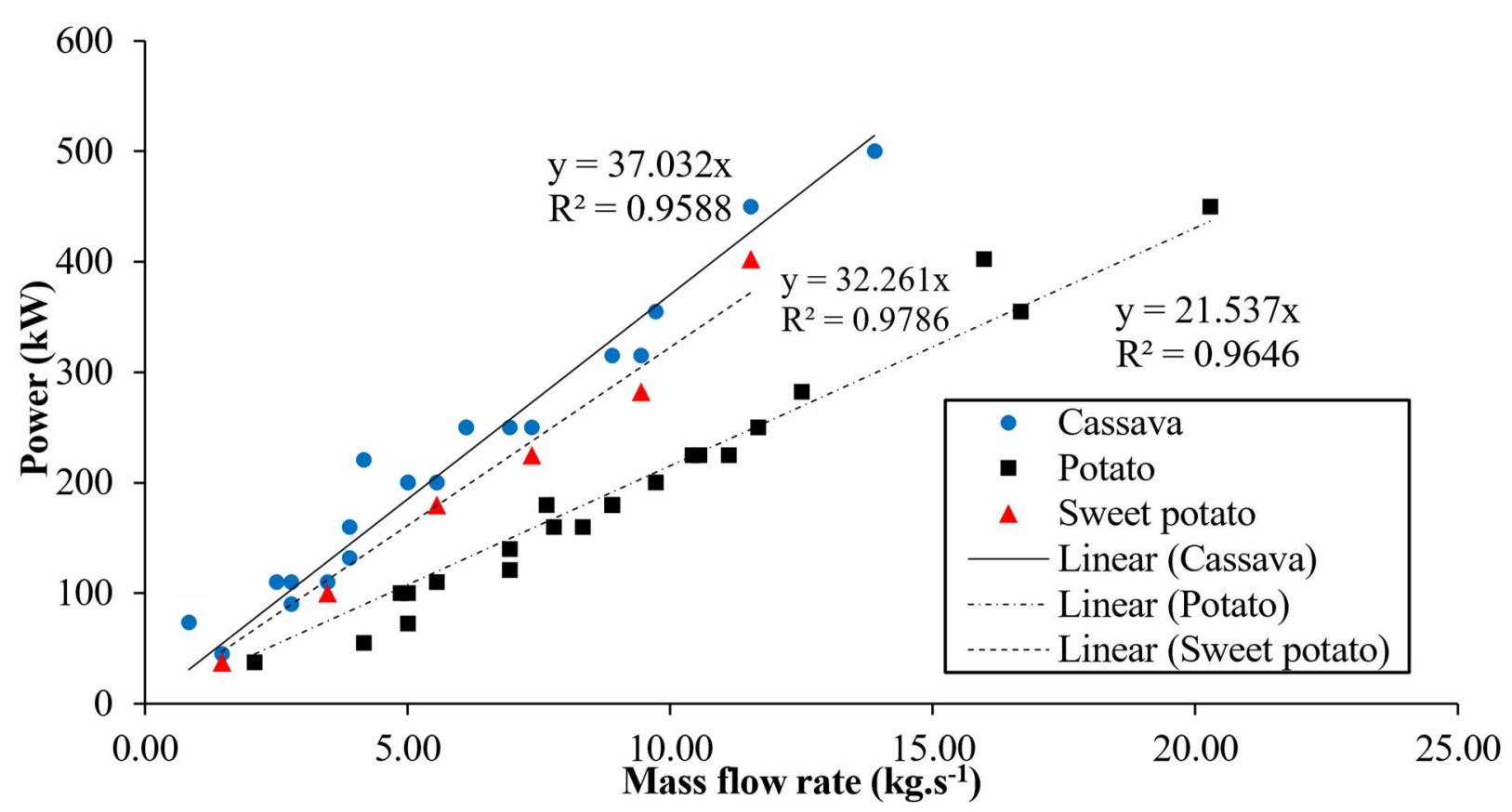

FIGURE 3. Power curves in function of mass flow rate for industrial feeders with cassava $(\bullet)$, potato $(\boldsymbol{\bullet})$, and sweet potato $(\boldsymbol{\Lambda})$ from the manufacturers' catalogs Bosida ${ }^{\circledR}$ (Hohhot, China), EBS ${ }^{\circledR}$ (Quatro Pontes - PR, Brazil), Konex ${ }^{\circledR}$ (Singapore), and Larsson ${ }^{\circledR}$ (Bromölla, Sweden).

Figure 3 shows the fitting equations that represent the behavior between the mass flow of raw material $\left(\dot{\mathrm{m}}_{\mathrm{m}}\right)$ and the electric engine power $(\mathrm{P})$ used in the equipment, allowing establishment of the specific energy consumption $\left(E_{e}\right)$ given by equation (1). The results for the industrial grater are $37.03 \mathrm{~kJ} \cdot \mathrm{kg}^{-1}$ for cassava, $21.54 \mathrm{~kg} \cdot \mathrm{kg}^{-1}$ for potatoes, and $32.26 \mathrm{~kg} \cdot \mathrm{kg}^{-1}$ for sweet potatoes. For the hammer mill adapted for arrowroot, the specific consumption was 31.47 to $48.91 \mathrm{~kJ}^{\mathrm{kg}}{ }^{-1}$, close to that of the industrial grater at $37.03 \mathrm{~kJ}^{.} \mathrm{kg}^{-1}$ in the disintegration of cassava roots.

Notably, in some disintegration tests with arrowroot, it was not possible to maintain a continuous mass flow rate due to accumulation of the fibrous material inside the mill
(Figure 4), which is due to the characteristics of this raw material. Although not described in literature, arrowroot rhizomes present thicker fibers compared to other raw materials, and these fibers could not be completely ruptured during disintegration. This problem may require occasional stops to clean the mill or should be solved as with sugar cane stalks, which also have abundant fibers (Thammasittirong et al., 2017), by adding a pre-preparation operation. In our experiment with the cleaning operation, the raw material feed was in a more continuous way.

For longer fibers, retention portions were observed as starch agglomerations along the fibers, which are shown in Figure 4. This phenomenon is also reported in literature for other raw materials, at up to $1 \%$ for potatoes (Garcia et al., 2015) and from 42 to $47 \%$ for cassava (Farias et al., 2014). 

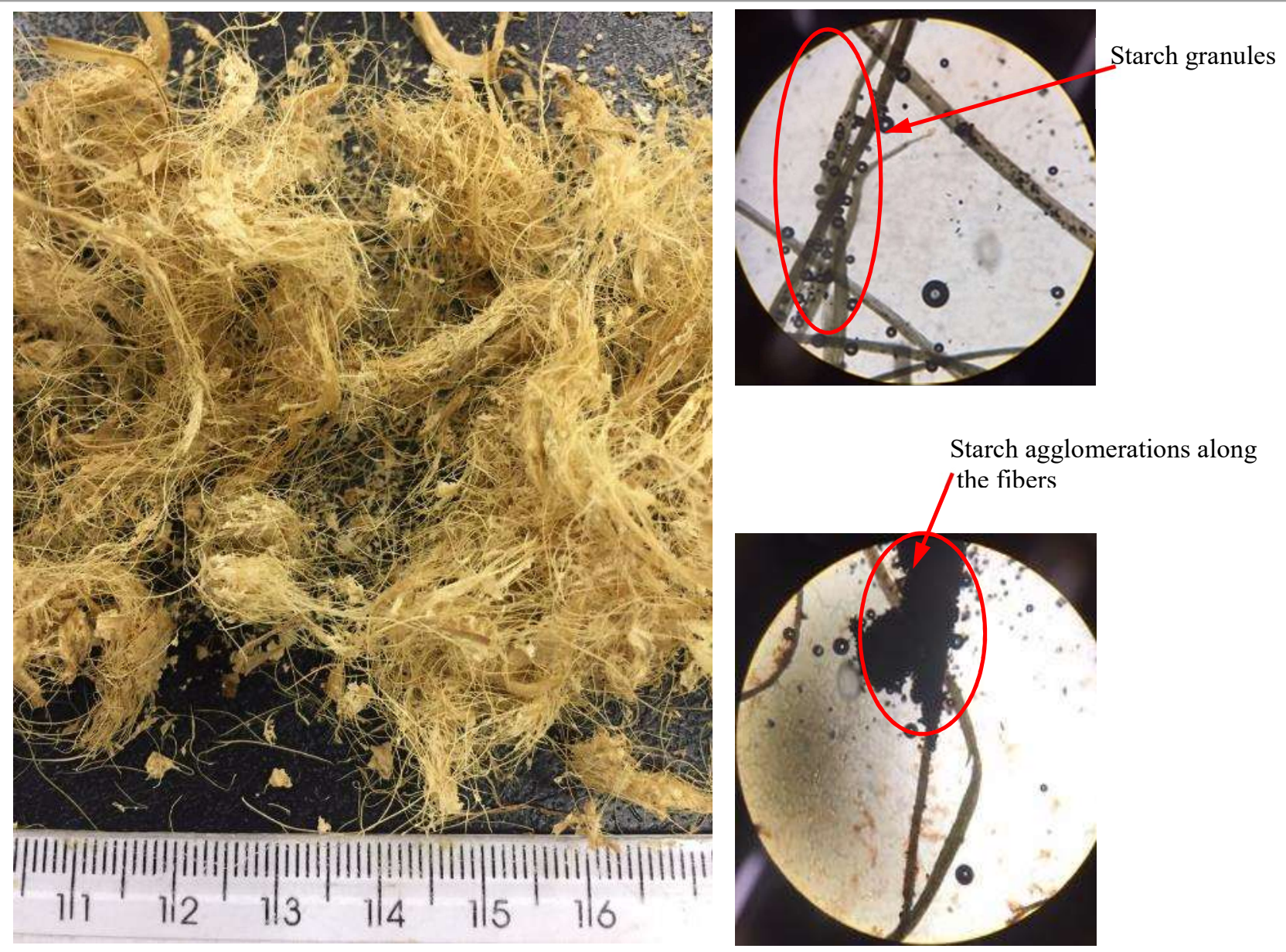

FIGURE 4. General aspects and microscopy (400x) of fibrous material accumulated during extraction of $10 \mathrm{~kg}$ of arrowroot. Highlighted for arrowroot starch agglomerates in the fibers.

No references were found regarding fiber mass accumulation where arrowroot rhizomes were grated. However, in general, this operation is performed manually or by a handcrafted process, where there is no great disorder. However, for mechanized scales, it is a concern, which reinforces the proposal of a pre-preparation step before grinding.

It is important to consider that cassava bagasse is the industrial residue from starch extraction (Fiorda et al., 2013), but is very different, i.e., more humid and viscous. However, in tests performed with cassava roots, the same problem was not observed and stops for cleaning were not necessary.

\section{Granulometric distribution and mean particle size}

In Figure 5, the granulometric distribution of samples obtained with the adapted hammer mill with perforated plates of $1.2,1.5$, and $1.8 \mathrm{~mm}$ were compared with the granulometry obtained with the grating pattern adopted, obtained with industrial cassava bagasse under the same conditions. The data shows that disintegration with new blades $(\mathrm{C} 1)$ provided a thinner mass, with a granulometric distribution accumulated in a larger percentage with the smaller diameters (maximum of $85.4 \pm 1.4 \%$ ). The profile obtained with the grated cassava mass was closer to that of the similar mass obtained with the perforated plate $1.2 \mathrm{~mm}$, whereas the granulometric distribution of the hammer mill for the different perforated plates was close, mainly between perforations of $1.2 \mathrm{~mm}$ $(78.3 \pm 1.0 \%)$ and $1.5 \mathrm{~mm}$ and $(77.4 \pm 0.3 \%)$ for smaller particle diameters. 


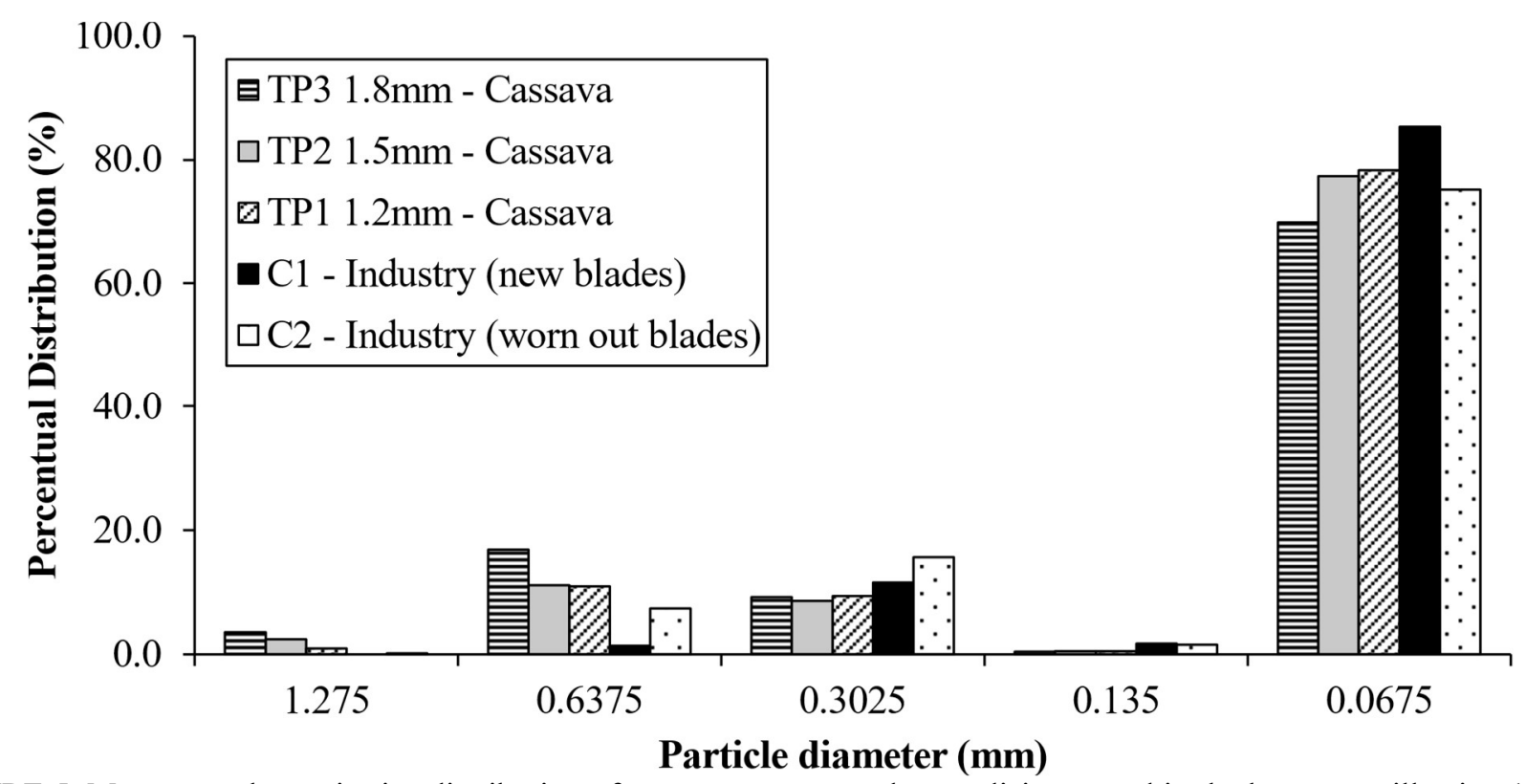

FIGURE 5. Mean granulometric size distribution of cassava roots grated mass disintegrated in the hammer mill using 1.8, 1.5, and $1.2 \mathrm{~mm}$ mesh sieves, compared to samples processed in a commercial grater (C1 and $\mathrm{C} 2)$.

When the disintegrated arrowroot and cassava mass in the hammer mill are compared as in Figure 6, the mill performance is observed to be equivalent $(85.8 \pm 0.1 \%$ for perforated plate of $1.5 \mathrm{~mm}$ and $88.4 \pm 0.1 \%$ for perforated plate of $1.2 \mathrm{~mm}$ ), as they do not differ, even when compared

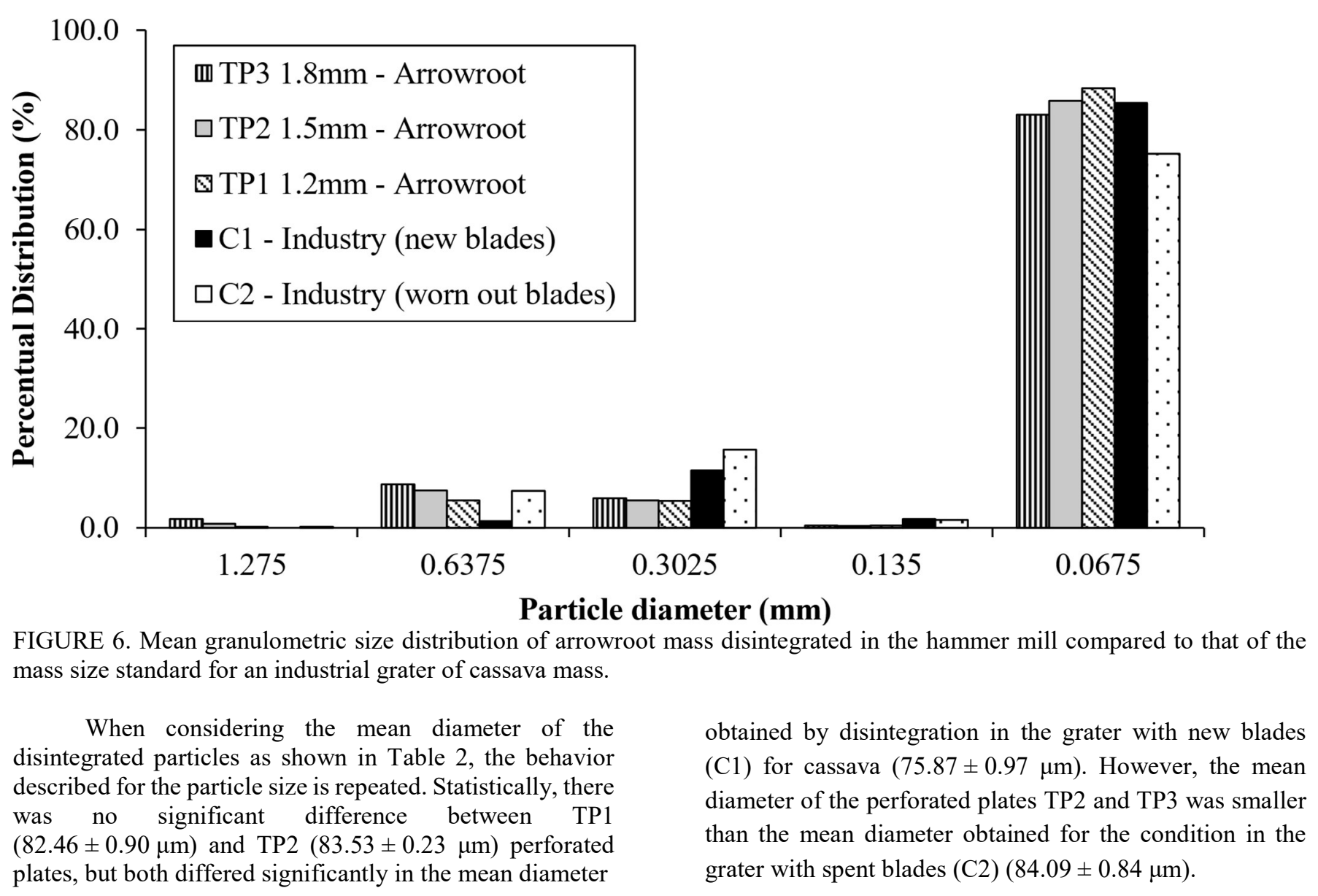

FIGURE 6. Mean granulometric size distribution of arrowroot mass disintegrated in the hammer mill compared to that of the mass size standard for an industrial grater of cassava mass.

When considering the mean diameter of the disintegrated particles as shown in Table 2, the behavior described for the particle size is repeated. Statistically, there was no significant difference between TP1 $(82.46 \pm 0.90 \mu \mathrm{m})$ and TP2 $(83.53 \pm 0.23 \mu \mathrm{m})$ perforated plates, but both differed significantly in the mean diameter to the grater with new sheet sets $(85.4 \pm 1.4 \%)$ and except for the perforated plate of $1.8 \mathrm{~mm}(83.0 \pm 0.2 \%)$. This difference may be because arrowroot fibers (Figure 4) are larger and thicker than cassava roots, forming a mass that was retained in the hammer mill. 
TABLE 2. Sauter diameter $\left(D_{s}\right)$ evaluated between grater mass for new blades $(C 1)$, worn blades $(C 2)$, and perforated plates (TP1, TP2 and TP3) in micrometers $(\mu \mathrm{m})$.

\begin{tabular}{llllll}
\hline & \multicolumn{2}{c}{ Industrial grater } & \multicolumn{3}{c}{ Hammer mill } \\
\hline Cassava & $\mathrm{C} 1(1.2 \mathrm{~mm})$ & $\mathrm{C} 2(1.2 \mathrm{~mm})$ & $\mathrm{TP} 1(1.2 \mathrm{~mm})$ & $\mathrm{TP} 2(1.5 \mathrm{~mm})$ & $\mathrm{TP} 3(1.8 \mathrm{~mm})$ \\
Arrowroot & \multirow{2}{*}{$75.87 \pm 0.97^{\mathrm{A}}$} & \multirow{2}{*}{$84.09 \pm 0.84^{\mathrm{B}}$} & $82.46 \pm 0.90^{\mathrm{Ba}}$ & $83.53 \pm 0.23^{\mathrm{Ba}}$ & $91.02 \pm 0.88^{\mathrm{Ca}}$ \\
& & & $74.64 \pm 0.09^{\mathrm{Ab}}$ & $76.62 \pm 0.06^{\mathrm{Ab}}$ & $78.83 \pm 0.15^{\mathrm{Cb}}$ \\
\hline
\end{tabular}

The average of three repetitions with standard deviation followed by the same lowercase letter in the column and upper case in the row do not differ significantly from each other by Tukey's test at the 5\% error probability level.

When comparing the mean diameter of the pattern of cassava grated mass obtained in the industrial grater with the results obtained for arrowroot mass obtained in the adapted hammer mill, the results may indicate that the performance was similar because the mean diameters of the arrowroot in the perforated plates TP1 $(74,64 \pm 0.09 \mu \mathrm{m})$ and TP2 $(76.62 \pm 0.06 \mu \mathrm{m})$ did not differ in the condition of new blades (C1) for cassava $(75.87 \pm 0.97 \mu \mathrm{m})$. Even in the TP3 perforated plate $(78.83 \pm 0.15 \mu \mathrm{m})$, the material presented a lower particle size than that in the grater with spent blades (C2) $(84.09 \pm 0.84 \mu \mathrm{m})$. This result may reduce the cost of starch extraction with the hammer mill when compared to the cost of cassava root graters as it would not be necessary to change the blades used.

When the Sauter diameters are compared in the columns, i.e., the same operating conditions of the hammer mill for different raw materials, all the data differ, but always, the particles obtained with the arrowroot had smaller mean diameters than those obtained with the cassava mass.

\section{CONCLUSIONS}

The choice of the hammer mill proved to be adequate for the small scale due to the easy adaptation of small commercial mills by replacing only the rotor, reducing the maintenance of saw teeth compared to graters, and due to its equivalent performance compared to industrial equipment. The use of an adapted hammer mill may also reduce the cost of starch extraction when compared to the cost with the use of graters, as it would not be necessary to change the blades used.

The tests highlighted the differences found when processing the raw materials in the same equipment due to its characteristics. While the mass flow rate for cassava was continuous, grating of the arrowroot rhizomes led to retention of the fibrous mass, which interrupted the exit flow of the residue and required stops for cleaning. This result indicates the need for a pre-preparation of the rhizomes such as a perpendicular cut in the fiber direction to allow increased fluidity of disintegration.

In conclusion, use of perforated plates of 1.2 and $1.5 \mathrm{~mm}$ did not interfere with the particle size distribution and the mean diameter of the disintegrated material. In this case, using the perforated plate of $1.5 \mathrm{~mm}$ is more advantageous compared to the perforated plate of $1.2 \mathrm{~mm}$ as it facilitates passage of the material with suitable granulometry for extracting starch, allowing a higher mass flow rate in the feed of the hammer mill. Moreover, the choice of the $1.5 \mathrm{~mm}$ diameter perforated plate is as efficient as the performance of industrial equipment.

\section{REFERENCES}

Barth M, Renner JS, Nunes MF, Sanfelice GR (2016) Características do trabalho na agricultura familiar e sua influência na emigração dos jovens. Iluminuras 17(2016):256-276. DOI: http://dx.doi.org/10.22456/19841191.64569

\section{BOSIDA (2016) RU Series Super Rasper. BOSIDA.}

Available:

http://www.bosidachina.com/English/zlkjpor_view.asp?id $=36$. Accessed: May 09, 2018.

Cereda MP, Vilpoux O (2003) Processo de produção de fécula de mandioca: comparação Brasil, Tailândia e China. In Cereda MP (ed) Agricultura: Tuberosas Amiláceas Latino Americanas. Volume 3: Tecnologias, usos e potencialidades de tuberosas amiláceas latino americanas. São Paulo, Fundação Cargill, 2 ed. p143-175.

Da G, Dufour D, Giraldo A, Moreno M, Tran T, Velez G, Sanchez T, Le-Thanh M, Marouze C, Marechal PA (2013) Cottage Level Cassava Starch Processing Systems in Colombia and Vietnam. Food and Bioprocess Technology 6(8):2213-2222. DOI: http://dx.doi.org/10.1007/s11947012-0810-0

EBS (2015) Catálogo técnico Cevadeira 300T - Manual de operação e manutenção. EBS, 12p.

Farias FO, Jasko AC, Colman TAD, Pinheiro LA, Schnitzler E, Barana AC, Demiate IM (2014) Characterisation of Cassava Bagasse and Composites Prepared by Blending with Low-Density Polyethylene. Brazilian Archives of Biology and Technology 57(6):821-830. DOI: https://dx.doi.org/10.1590/S1516-8913201402506

Fiorda FA, Soares Júnior M, Silva FA, Souto LRF, Grossmann MVE (2013) Farinha de bagaço de mandioca: Aproveitamento de subproduto e comparação com fécula de mandioca. Pesquisa Agropecuária Tropical 43(4):408416. DOI: https://doi.org/10.1590/S198340632013000400005

Garcia EL, Carmo EL, Pádua JG, Leonel M (2015) Potencialidade de processamento industrial de cultivares de batatas. Ciência Rural 45(10):1742-1747. DOI: https://dx.doi.org/10.1590/0103-8478cr20140072

Granados CC, Guzman CLE, Acevedo CD, Díaz MM, Herrera AA (2014) Propiedades funcionales del almidon de sagu (Maranta arundinacea). Biotecnología en el Sector Agropecuario y Agroindustrial 12(2):90-

96. Available: http://www.scielo.org.co/scielo.php?script=sci arttext\&pid=S1692-35612014000200010\&lng=en\&tlng=es. Accessed May 09, 2018. 
Groxko M (2016) Mandioca - Análise da Conjuntura Agropecuária. Departamento de Economia Rural (DERAL). Available: http://www.agricultura.pr.gov .br/arquivos/File/deral/Prognosticos/2017/Mandioca_2016 _17.pdf. Accessed: Nov 21, 2017.

Guilherme DO, Branco FP, Madeira NR, Brito VH, Oliveira CE, Jadoski CJ, Cereda MP (2019) Starch Valorization From Corn, Tuber, Rhizome, and Root Crops: The Arrowroot (Maranta arundinacea L.) Case. In: Clerici MTPS, Schmiele M (eds). Starches for food application chemical, technological and health properties. London, Academic Press, p167-222. DOI: http://doi.org/10.1016/B978-0-12-809440-2.00005-8

Jordan RA, Baldassin Junior R, Cortez LAB, Motomiya AVA (2016) Caracterização granulométrica de biomassa polidispersa pelo método de peneiramento mecânico.

Engenharia Agrícola 36(1):102-113. DOI:

http://dx.doi.org/10.1590/1809-4430-

Eng.Agric.v36n1p102-113/2016

KONEX (2016) Rasper MODEL DRS/DRD 300, 400, 500, 600. KONEX. Available:

http://www.konexindo.com/index.php/rasper. Accessed May 09, 2018.

LARSSON (2016) LARSSON Rasper GL550/300.

LARSSON. Available:

https://www.larssonsweden.com/wp-

content/uploads/2016/06/DO0044001-A3-EN-Rasper-

GL550.pdf. Accessed May 09, 2018.

Leonel M, Cereda MP (2002) Caracterização físicoquímica de algumas tuberosas amiláceas. Ciência e Tecnologia de Alimentos 22(1):65-69. DOI: http://dx.doi.org/10.1590/S0101-20612002000100012.

Malinis AP, Pacardo CO (2012) Adaptation of arrowroot (Maranta Arundinacea) processing technologies in Typhoon prone marginal areas in Bicol. OIDA, International Journal of Sustainable Development 4(3):5162. Available: https://ssrn.com/abstract $=2054174$
Moreno, LB, Torales EP, Heid DM, Zárate NAH, Abrão MS (2017) Influence of plant density and hilling on yield and profitability of arrowroot. Pesquisa Agropecuária Tropical 47(4):465-471. DOI:

https://dx.doi.org/10.1590/1983-40632017v4748643

Sá RM, Miranda CS, José NM (2015) Preparation and Characterization of Nanowhiskers Cellulose from Fiber Arrowroot (Maranta arundinacea). Materials Research 18 (Suppl. 2):225-229. DOI: https://dx.doi.org/10.1590/15161439.366214

Sajeev MS, Balagopalan C (2005) Performance evaluation of multi-purpose mobile starch extraction plant for small scale processing of tuber crops. Journal of Root Crops 2:106-110.

Saengchan K, Nopharatanaa M, Lerdlattapornb R, Songkasiri W (2015) Enhancement of starch-pulp separation in centrifugal-filtration process: Effects of particle size and variety of cassava root on free starch granule separation Food and Bioproducts Processing 95:208-217. DOI:

http://dx.doi.org/10.1016/j.fbp.2015.05.008

Sajeev MS, Nanda SK, Sheriff JT (2012) An Efficient Blade Type Rasper for Cassava Starch Extraction. Journal of Root Crops 38(2):151-156.

Sheriff JT, Balagopalan C (1999) Evaluation of multi-purpose starch extraction plant. Tropical Science 39:147-152.

Souza LH, Dias GP, Souza LCV, Dias IG, Rodrigues DE (2010) Avaliação da demanda energética de um desintegrador-picador-moedor (DPM) na moagem de milho. REVENGE Engenharia na Agricultura 18(9):480-487.

Thammasittirong SNR, Chatwachirawong P, Chamduang T, Thammasittirong A (2017) Evaluation of ethanol production from sugar and lignocellulosic part of energy cane. Industrial Crops and Products 108(1):598-603. DOI: http://dx.doi.org/10.1016/j.indcrop.2017.07.023 